\title{
LONG-TERM RESULTS IN HAIRY CELL LEUKEMIA TREATED WITH 2-CHLORODEOXYADENOSINE
}

\author{
Ladislav Chrobák, Pavel Žák, Karel Podzimek1, Lenka Plíšková, \\ Jaroslava Foglová, Vladimír Maisnar, Petr Dulíček, Karel Dědič̉ \\ Department of Clinical Hematology, Charles University, Faculty of Medicine, Hradec Králové; \\ (Head: prof. MUDr. L. Chrobák, CSc.) \\ ${ }^{1}$ Ist Department of Medicine, Charles University, Faculty of Medicine, Hradec Králové; \\ (Head: prof. MUDr. J. Kvasnička, CSc.) \\ ${ }^{2}$ Institute of Clinical Biochemistry and Diagnostics, Charles University, Faculty of Medicine, Hradec Králové; \\ (Head: doc. MUDr. V. Palička, CSc.) and \\ ${ }^{3}$ Department of Pathological Anatomy, Charles University, Faculty of Medicine, Hradec Králové; \\ (Head: prof. MUDr. I. Šteiner, CSc.)
}

Supported by Grant No 3690-2 IGA from the Ministry of Health of the Czech Republic.

Summary: We treated 19 patients with hairy cell leukemia (HCL) with 2-chlorodeoxyadenosine. 15 patients followed up at least 6 months were evaluated. The follow up period varied between 6 months and 37 months (median, 19 months). 8 patients were previously treated. The overall response in 15 evaluable HCL patients was $100 \%$, with $87 \%$ complete hematological remissions including three patients with retroperitoneal and mediastinal lymphadenopathy and one patient with leukemic infiltrates of the cornea; $13 \%$ of patients achieved partial hematological remission. Soluble interleukin - 2 receptor (sIL-2R) considered as a reliable non-invasive marker of HCL tumor burden dropped from the median of $1350 \mathrm{pM} / \mathrm{ml}$ (range 188 to $9000 \mathrm{pM} / \mathrm{ml}$ ) to the median of $84,3 \mathrm{pM} / \mathrm{ml}$ (range 37 to $382 \mathrm{pM} / \mathrm{ml}$ ) RdW which reflects the anisocytosis of red cells decreased after therapy from the median of $20,6 \%$ (range $13,1-25,0 \%$ ) to the median of $13,7 \%$ (range $12,4-16,3 \%$ ).

Key words: HCL; Therapy with chlorodeoxyadenosine; Long-term results; sIL-2R; $R d W$

Hairy cell leukemia is a chronic lymphoproliferative disorder characterized by abnormal mononuclear cells of $\mathrm{B}$ lymphocyte origin infiltrating bone marrow and spleen. Patients, usually middle-aged men, often present with some combination of anemia, neutropenia, thrombocytopenia and splenomegoly. There is currently no single antibody which identifies an antigen unique to the hairy cells. These cells mostly demonstrate the pan-B-cells antigens $\mathrm{Ig}+$, CD 19+, CD 20+, CD 22+, and usually lack surface CD 5- and CD 21. Recently DBA 44, the hairy cell associated monoclonal antibody, has been used for demonstration of hairy cell in biopsy sections. Hairy cells characteristically express the receptor for interleukin-2 (IL-2R) on their membrane and although sIL-2R production is not unique only to hairy cells, the serum levels can be used as a marker of leukemic cell burden at diagnosis and for monitoring therapeutic efficiency, and for the detection of minimal residual disease $(1,4,17)$.

Although the disease is relatively indolent, the majority of patients require treatment for life-treatening pancytopenia or symptomatic splenomegaly. Slenectomy has been used for over three decades as the initial treatment option for HCL. Splenectomy has been certainly beneficial for some patients (3) resulting in a significant improvement of their pancytopenia but splenectomy has no effect on bone marrow infiltration by leukemic cells. As a result, approximately $50 \%$ of splenectomized patients have recurrent cytopenias that require systemic therapy. Interferon-alpha was the first drug in which de possibility to cure HCL was originally considered. This expectance was not fulfilled. Interferon-alpha was highly effective in the management of HCL but it did not have a curative potential. Relapses were observed wihin the $6^{\text {th }}$ and $28^{\text {th }}$ month after the with drawal of the therapy with interferon alpha. The introduction of two new purine analogues, 2-deoxycoformycin (DCF) and 2-chlorodeoxyadenosine (2-CdA) has dramatically improved treatment option in the last years (16). 2-CdA has been shown to induce complete remission (CR) in the majority of patients, with only a single cycle and a paucity of toxicities $(7,16)$. However, persistence of minimal residual disease in the bone marrow, detected either by immunohistochemistry or polymerase chain reaction suggests that some patients are at risk of relapse $(6,10)$. The purpose of this study is to determine the durability of remissions and relapse rate in patients with HCL treated with a single cycle of $2 \mathrm{CdA}$. 


\section{Patients and Methods}

Since 1994 when 2-CdA became available in this country we have administered 2-CdA in 19 patients with HCL.

The diagnosis of HCL was based on the presence of morphologically characteristic cells in the peripheral blood and/or the bone marrow, demonstration of tartarate resistant acid phosphatase activity in the neoplastic cells (20), typical histologic pattern in bone marrow biopsies with infiltration of malignant cells characteristically surrounded by a rim of pale cytoplasm resulting in clearly separated nuclei (2). In all 6 splenectomized patients the diagnosis of HCL has been reconfirmed by the histologic finding in the spleen showing heavy infiltration of the red pulp by abnormal interdigitating mononuclear cells and the presence of blood-filled spaces lined by hairy cells, so called pseudosinuses (15).

The levels of sIL-2R were determined by a sandwich enzyme immunoassay (Immunoenzymometric assay Test Kit cat. 0559, IMMUNOTECH) normal values obtained by determination of sIL-2R in 20 healthy blood donors were $30,4 \pm 13,6 \mathrm{pM} / 1$.

The RdW (in \%) was determined by Coulter JT3.

Table 1: Patient Characteristics

\begin{tabular}{|c|c|}
\hline \multicolumn{2}{|l|}{ Characteristics } \\
\hline No of Patients & 15 \\
\hline \multicolumn{2}{|l|}{ Age (yr) } \\
\hline Median & 61 \\
\hline Range & $43-84$ \\
\hline \multicolumn{2}{|l|}{ Sex } \\
\hline Male & 12 \\
\hline Female & 3 \\
\hline \multicolumn{2}{|l|}{ Previous treatment } \\
\hline None & 7 \\
\hline Splenectomy & 4 \\
\hline IFN-alpha & 2 \\
\hline IFN-alpha, SPL & 1 \\
\hline IFN-alpha, SPL, IFN-alpha & 1 \\
\hline Duration of HCL before & $2 \mathrm{CdA}$ \\
\hline \multicolumn{2}{|l|}{ therapy (months) } \\
\hline Median & 13 \\
\hline Range & $1-137$ \\
\hline \multicolumn{2}{|l|}{ Bone marrow infiltration } \\
\hline Diffuse & 10 \\
\hline Interstitial to diffuse & 2 \\
\hline Interstitial & 3 \\
\hline \multicolumn{2}{|l|}{$\mathrm{Hgb}(\mathrm{g} / 1)$} \\
\hline Median & 107 \\
\hline Range & $(88-149)$ \\
\hline \multicolumn{2}{|l|}{$\operatorname{ACN}\left(\times 10^{9} / 1\right)$} \\
\hline Median & 0,7 \\
\hline Range & $(0,4-7,7)$ \\
\hline \multicolumn{2}{|l|}{ Platelets $\left(\times 10^{9} / 1\right)$} \\
\hline Median & 92 \\
\hline Range & $(35-218)$ \\
\hline
\end{tabular}

SPL, splenectomy; ACN, absolute neutrophil count
The main patient characteristics are listed in table 1 . Out of 19 patients 15 with follow up period more than 6 months were avaluated. There were 12 men and 3 women, with an age range of 43 to 84 years (median, 61 years). Seven patients were previously untreated. Eight patients were previously treated, four with splenectomy, two with interferon-alpha (IFN-alpha) only, one with splenectomy then IFN-alpha and one with IFN-alpha then splenectomy followed by IFN-alpha and then 2-CdA. The duration of HCL befor the start of 2-CdA therapy varied between 1 and 137 months. The bone marrow biopsy performed before the administration of 2-CdA revieled diffuse infiltration in 10 patients, interstitial with some areas of diffuse infiltration in 2 and interstitial infiltration in 3 patients. The hemoglobin levels were 88 to $149 \mathrm{~g} / 1$ (median, $107 \mathrm{~g} / \mathrm{l}$ ) absolute neutrophil counts 0,4 to $7,7 \times 10^{9} / 1$ (median, 0,7 x $10^{9} / 1$ ), platelet counts 35 to $218 \times 10^{9} / 1$ (median, $92 \times$ $\left.10^{9} / 1\right)$.

\section{Eligibility}

Eligibility criteria included the following:

(1) Conf irmed diagnosis of HCL based on the criteria mentioned above (2) follow up at least six months, (3) evidence of active disease, including any of the following: neutropenia (absolute neutrophil count < 1,5 x 10 $/ 1$ ), anemia (hemoglobin level $<120 \mathrm{~g} / 1$ ), thrombocytopenia (platelet count $<100 \times 10^{9} / 1$ ), retroperitoneal lymphadenopathy.

\section{Administration of 2-CdA}

All patients received a single cycle of 2-CdA (Leustatin, Cladribine, Orthobiotech, Raritan, NY) at a dose of 0,1 $\mathrm{mg} / \mathrm{kg} / \mathrm{d}$ by continuous intravenous infusion for 7 days.

\section{Supportive care}

Neutropenic patients who developed fever greater than $38{ }^{\circ} \mathrm{C}$ were given broad-spectrum antibiotics. However many such patients with sterile blood cultures had no evidence of infection. Packed red blood cells were not routinely transfused, but rather were administered only for symptomatic anemia. Platelets were administered prophylactically if the platelet count was less than 10 to $15 \times 10^{9} / 1$. Hematopoetic growth factors were administered in only 4 patients with severe neutropenia.

\section{Initial evaluation}

At the time of study entry, all patients had a complete history and physical examination; complete blood cell count (CBC) with differential and platelet count; computed tomographic (CT) or ultrasound (US) scans of the chest, abdomen, and pelvis; marrow aspirate and unilateral bone core biopsy.

Patients were monitored without other therapy and were then reevaluated at 3 and 6 months with a unilateral bone marrow aspirate and biopsy and CT or US scans of the abdomen and pelvis. 


\section{Response criteria}

Patients were evaluated for response 6 months after the initiation of 2-CdA. CR (complete hematologic remission) required all of the following:

(1) complete absence of hairy cells in the peripheral blood

(2) normalization of peripheral blood counts (hemoglobin level > $120 \mathrm{~g} / 1$, white blood cell count $>3 \mathrm{x} 10$ (/l, absolute neutrophil count $>1,5 \times 10^{9} / 1$, platelet count $>100 \mathrm{x}$ $10^{9} / 1$, disappearance of retroperitoneal lymphadenopathy and hepatosplenomegaly by CT or US scans.

A PR (partial remission) required all of the following:

(1) Failure of normalization in one of low peripheral blood counts

(2) Reduction of greater than $50 \%$ in abnormal lymphadenopathy or hepatosplenomegaly.

Relaps was defined: as reappearance of hairy cells in the peripheral blood and decrease of blood cell count below the values required for CR; increase of lymphadenopathy and/or hepatosplenomegaly.

\section{Results}

Out of 15 assessable patients, 13 (87 \%) achieved CR with a single cycle of 2-CdA; 2 (13\%) achieved PR. Therefore, the overall response rate with a single cycle was $100 \%$. Of the 2 patients achieving PR, the platelet count was $48 \mathrm{x}$ $10^{9} / 1$ in the first and $90 \times 10^{9} / 1$ in the second one (table 2). Retroperitoneal and mediastinal lymphadenopathy disappeared in all three patients in whom it was noticed before the initiation of 2-CdA therapy. In one patient with infiltrates of cornea these infiltrates disappeared as well as mediastinal and retroperitoneal lymphadenopathy which were present before the initiation of therapy with 2-CdA. No patient died and no patient relapsed during the follow up which varied between 6 and 37 months (median, 19 months).

Table 2: Blood cell counts in 15 patients with HCL before and after therapy with 2-CdA

No Name Sex ANC (x10 $/ 1) \quad \mathrm{Hgb}(\mathrm{g} / \mathrm{l})$ Platelets $\times 10^{9} / 1$ Remission before after before after before after

$\begin{array}{rccrrrrrrl}1 & \text { Z.J } & \text { M } & 0,4 & 2,2 & 35 & 123 & 35 & 112 & \text { CR } \\ 2 & \text { L.Z } & \text { M } & 1,2 & 5,0 & 128 & 148 & 293 & 412 & \text { CR } \\ 3 & \text { T.D } & \text { F } & 1,4 & 2,6 & 102 & 139 & 218 & 344 & \text { CR } \\ 4 & \text { M.O } & \text { M } & 7,7 & 4,0 & 120 & 154 & 106 & 173 & \text { CR } \\ 5 & \text { B.J } & \text { M } & 1,3 & 7,0 & 130 & 159 & 110 & 268 & \text { CR } \\ 6 & \text { M.L } & \text { F } & 0,6 & 5,8 & 118 & 147 & 140 & 422 & \text { CR } \\ 7 & \text { Ž.J } & \text { M } & 0,4 & 2,9 & 88 & 161 & 92 & 185 & \text { CR } \\ 8 & \text { F.J } & \text { M } & 1,2 & 2,0 & 106 & 141 & 111 & 154 & \text { CR } \\ 9 & \text { S.V } & \text { F } & 0,4 & 5,5 & 101 & 129 & 87 & 192 & \text { CR } \\ 10 & \text { D.S } & \text { M } & 0,6 & 3,6 & 132 & 152 & 89 & 182 & \text { CR } \\ 11 & \text { V.J. } & \text { M } & 1,6 & 9,6 & 60 & 128 & 190 & 178 & \text { CR } \\ 12 & \text { Z.S. } & \text { M } & 1,7 & 7,9 & 107 & 142 & 79 & 131 & \text { CR } \\ 13 & \text { G.A } & \text { M } & 0,7 & 3,3 & 88 & 125 & 25 & 48 & \text { PR } \\ 14 & \text { M.W } & \text { M } & 0,7 & 4,4 & 104 & 168 & 58 & 90 & \text { PR } \\ 15 & \text { H.M } & \text { M } & 0,7 & 3,0 & 149 & 161 & 217 & 359 & \text { CR } \\ & & & & & & & & & \\ \text { Median } & & 0,7 & 4,0 & 107 & 147 & 92 & 183 & \end{array}$

Vysvětlivky: ANC - absolute neutrophil count CR - complete remission PR - partial remission
The sIL-2R levels were increased in all patients before the initiation of the therapy with $2 \mathrm{CdA}$ in the range of 188 to $9000 \mathrm{pM} / \mathrm{ml}$ (median, $1350 \mathrm{pM} / \mathrm{ml}$ ), they decreased after the therapy to 37 to $382 \mathrm{pM} / \mathrm{ml}$ (median, $84,3 \mathrm{pM} / \mathrm{ml}$ ) -see fig. 1 . The lowest value of sIL-2R before initiation of therapy was in a patient treated previously with IFN-alpha, splenectomy and the second course of IFN-alpha therapy. Complete normalization of sIL-2R level after therapy was reached only in 2 patients $(34,7$ and $30,7 \mathrm{pM} / \mathrm{ml})$.

The $\mathrm{RdW}$ values were before the therapy between 13,1 $\%$ to $25,0 \%$ (median, 20,6 \%), after therapy between 12,4 and $16,3 \%$ (median, $13,7 \%$ ). The value $16,3 \%$ was in the patient who reached only the PR (see Fig. 2).

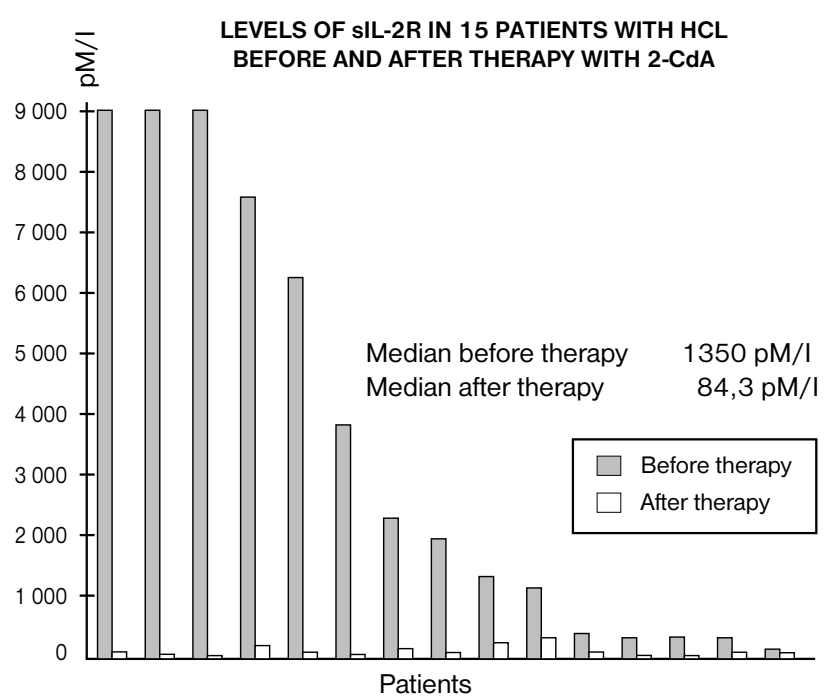

Fig. 1

VALUES OF RDW IN 15 PATIENTS WITH HCL BEFORE AND AFTER THERAPY WITH 2-CdA
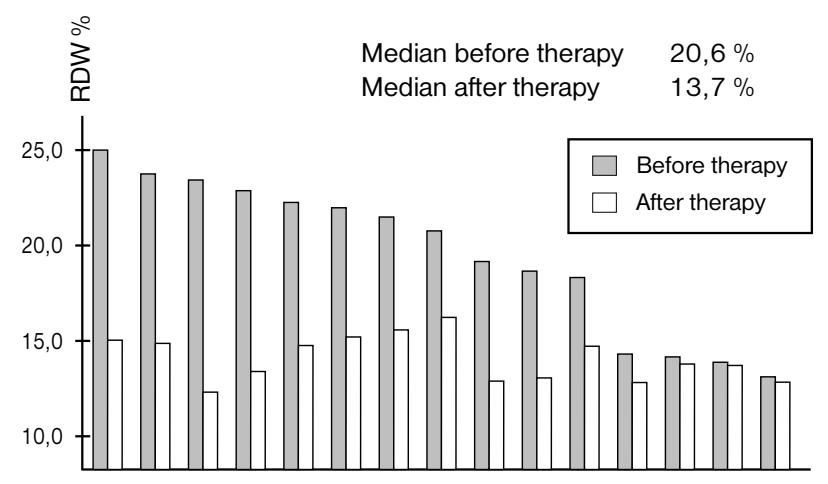

Fig. 2

\section{Discussion}

Our results confirm the effectiveness of $2-\mathrm{CdA}$ in the treatment of HCL as reported also by other study groups (see Tab. 3). In 327 patients collected from 7 study groups com- 
plete remission was achieved in $84 \%$ of patients and partial remission in $14 \%$. Therefore, the overall response rate with a single cycle of 2-CdA therapy was $98 \%$. Mercieca et al (14) stressed differences in response in patients with and without abdominal lymphadenopaty. In 7 patients with abdominal lymphadenopathy he achieved complete remission only in $4(57 \%)$. Similar results, four CR and two PR were reported by Hakimian et al. (7). We concluded in our previous study that retroperitoneal lymphadenopathy is an unfavourable sign usually heralding the terminal stage of the disease (22). In this study complete remission was achieved in all three patients with retroperitoneal lymphadenopathy including one patient with leukemic infiltrates of the cornea on both eyes as reported previously (21). Assessment for response in HCL should not be performed to early, as responses found incomplete 1-3 months after therapy may turn to be complete responses when assessed later. More than 1 year may be needed before clearance of malignant cells from the bone marrow is complete (12). Response to 2-CdA seems to be unaffected by previous therapies (18). Increased sIL-2R levels which are considered as non-invasive marker of HCL burden dropped considerably after 2-CdA therapy to be mostly only slightly above the upper limit of normal values, but only in two patients they were within normal limits. This observation is in agreement with the opinion that complete eradication of tumoral cells may be very rare.

Tab. 3: Results of treatment in patients treated with 2 - CDA

\begin{tabular}{|l|c|c|c|c|c|c|}
\hline Author & Number & $\begin{array}{l}\text { treated: } \\
\text { non-treat }\end{array}$ & CR: & PR: & CR+PR & Failure \\
\hline $\begin{array}{l}\text { Merciece } \\
\text { et al. }{ }^{14}\end{array}$ & 23 & $18: 5$ & $20(87 \%)$ & $3(13 \%)$ & $23(100 \%)$ & - \\
\hline $\begin{array}{l}\text { Tallman } \\
\text { et al. }{ }^{19}\end{array}$ & 50 & $13: 39$ & $40(80 \%)$ & $9(18 \%)$ & $49(98 \%)$ & $1(2 \%)$ \\
\hline $\begin{array}{l}\text { Lauria } \\
\text { et al. }\end{array}$ & 26 & $21: 5$ & $20(77 \%)$ & $6(23 \%)$ & $26(100 \%)$ & - \\
\hline $\begin{array}{l}\text { Saven } \\
\text { et al. }{ }^{18}\end{array}$ & 143 & $74: 69$ & $123(86 \%)$ & $17(12 \%)$ & $140(98 \%)$ & $3(2 \%)$ \\
\hline $\begin{array}{l}\text { Hoffman } \\
\text { et al. }{ }^{19}\end{array}$ & 48 & $27: 21$ & $42(88 \%)$ & $6(12 \%)$ & $48(100 \%)$ & - \\
\hline $\begin{array}{l}\text { Filleul } \\
\text { et al. }\end{array}$ & 22 & $12: 10$ & $17(77 \%)$ & $4(18 \%)$ & $21(95 \%)$ & $1(5 \%)$ \\
\hline $\begin{array}{l}\text { Chrobák } \\
\text { et al. }\end{array}$ & 15 & $8: 7$ & $13(87 \%)$ & $2(13 \%)$ & $15(100 \%)$ & - \\
\hline \begin{tabular}{l} 
Total \\
\hline
\end{tabular} & 327 & $\begin{array}{l}173: 154 \\
53 \%: 47 \%\end{array}$ & $275(84 \%)$ & $42(14 \%)$ & $322(98 \%)$ & $5(2 \%)$ \\
\hline
\end{tabular}

CR: complete remission, PR: partial remission

The RdW values reflecting the red cells anisocytosis were increased before the initiation of the therapy. This increased values were ascribed to the dyserythropoiesis and disappeared after successful therapy (5). Partial remission in one of our patients was associated only with a partial decrease of $\mathrm{RdW}$ from 20,6 to $16,3 \%$. In all the remaining patients almost normal values were achieved.
Whether the remission induced by 2-CdA may be considered as a cure is still unknown and is closely related to the discussion on eradication of malignant cells in complete responders. The present evidence suggests that residual disease persist in most if not in all complete remitters. Immunostaining of bone marrow biopsies with DBA 44 antibody in complete responders disclosed foci of malignant cells $(6,9)$.However, the persistence of residual disease is not necessarily predictive for relapse and only long-term follow up will settle this question. Data related to CR patients follow up are now available and suggest that relapses accumulate over time: median follow-up of 24, 13.5, 14, 23 and 19 months was associated with $22,14,7.6,3.5,14.2$ and 0 relapse rate respectively (see table 4 ). The recognition that HCL may relapse or progress after responding to 2-CdA does not rule out the possibility that some remitters will enjoy indefinite remission which practically coincides with the cure. 2-CdA represents a major advance in the management of patients with HCL with an easy administration and longterm excellent quality of life that follows therapy with 2-CdA.

Tab. 4: Relapse of patients with HCL treated with 2-CDA

\begin{tabular}{|c|c|c|c|c|c|c|}
\hline \multirow[t]{2}{*}{ Author } & \multirow{2}{*}{$\begin{array}{c}\text { No of } \\
\text { pat. }\end{array}$} & \multicolumn{2}{|c|}{ Relapses } & \multirow{2}{*}{$\begin{array}{l}\text { Median } \\
\text { Folow-up }\end{array}$} & \multirow{2}{*}{$\begin{array}{l}\text { Folow-up } \\
\text { (Months) }\end{array}$} & \multirow{2}{*}{$\begin{array}{c}\text { Relapse } \\
\text { (Months) }\end{array}$} \\
\hline & & no & $\%$ & & & \\
\hline $\begin{array}{l}\text { Merciece } \\
\text { et al. }\end{array}$ & 23 & 5 & 22 & 25 & $6-30$ & $6-17$ \\
\hline $\begin{array}{l}\text { Tallman } \\
\text { et al. }\end{array}$ & 50 & 7 & 14 & 24 & $12-44$ & $\begin{aligned} \text { CR: } & 12,24(2 \mathrm{x}) \\
& 25,35 \\
\text { PR: } & 6,45\end{aligned}$ \\
\hline $\begin{array}{l}\text { Lauria } \\
\text { et al. }\end{array}$ & 26 & 2 & 7,6 & 13,5 & - & 6,12 \\
\hline $\begin{array}{l}\text { Saven } \\
\text { et al. }\end{array}$ & 143 & 5 & 3,5 & 14 & - & $4-48$ \\
\hline $\begin{array}{l}\text { Hoffman } \\
\text { et al. }\end{array}$ & 48 & 5 & 10,4 & - & - & - \\
\hline $\begin{array}{l}\text { Filleul } \\
\text { et al. }\end{array}$ & 22 & 3 & 14,2 & 23 & - & $28-37$ \\
\hline $\begin{array}{l}\text { Chrobák } \\
\text { et al. }\end{array}$ & 15 & 0 & 0 & 19 & $6-37$ & - \\
\hline Total & 327 & 27 & 8,2 & & & \\
\hline
\end{tabular}

\section{References}

1. Ambrosetti A, Semenzato G, Prior M et al. Serum levels of soluble interleukin-2-receptor in hairy cell leukemia: a reliable marker of neoplastic bulk. $\mathrm{Br} \mathrm{J}$ Heamatol 1989;73:181-6.

2. Burke JS. The value of the bone marrow biopsy in the diagnosis of hairy cell leukemia. Am J Clin Pathol 1978;70:876-84.

3. Chrobák L, Podzimek K, Kerekeš Z et al. Long-term results in hairy cell leukemia treated by splenectomy. Neoplasma 1993;40:133-6.

4. Chrobák L, Podzimek K, Plíšková L. Serum soluble IL-2 receptor as reliable and non-invasive marker of disease ac- 
tivity in patients with hairy cell leukemia. Acta Medica (Hradec Králové) 1996;39:3-6.

5. Chrobák L, Žák P, Podzimek K et al. Dyserythropoiesis and increased RdW in hairy cell leukemia. The chronic leukeamias, International Conference, Prague (Abstract) 1996:p. 72.

6. Ellison DJ, Sharpe RW, Robbins BA et al. Immunomorphologic analysis of bone marrow biopsies after treatment with 2-chlorodeoxyadenosine for hairy cell leukemia. Blood 1994;84:4310-5.

7. Estey EH, Kurzrock R, Kantarjian H et al. Treatment of hairy cell leukemia with 2-chlorodeoxyadenosine for hairy cell leukemia. Blood 1992;79:882-7.

8. Filleul B, Delannoy A, Ferrant A et al. A single course of 2-chlorodeoxyadenosine does not eradicate leukemic cells in hairy cell leukemia patients in complete remission. Leukemia 1994;7:1153-6.

9. Hakimian D, Tallman MS, Hogan DK et al. Prospective evaluation of internal adenopathy in a cohort of 43 patients with hairy cell leukemia. J Clin Oncol 1994;12:268-72.

10. Hakimian D, Tallman MS, Kiley $C$ et al. Detection of minimal residual disease by immunostaining of bone marrow biopsies after 2-chlorodeoxyadenosine for hairy cell leukemia. Blood 1993;82:1798-1802.

11. Hoffman M, Janson D, Aggarwal A et al. Long term results after treatment of hairy cell leukemia (HCL) with 2-chlorodeoxyadenosine (2-CdA). Blood 1995;86(Suppl. 1):351a.

12. Juliusson G, Heldal D, Hippe E et al. Subcutaneous injections of 2-chlorodeoxyadenosine for symptomatic hairy cell leukemia. J Clin Oncol 1995;13:989-95.

13. Lauria F, Benfenati D, Raspadori D et al. High complete remission rate in hairy cell leukemia treated with 2-chlorodeoxyadenosine. Leuk Lymph 1993;11:399-404.

14. Mercieca J, Matutes E, Emmett E et al. 2-Chlorodeoxyadenosine in the treatment of hairy cell leukaemia: differences in response in patients with and without abdo- minal lymphadenopathy. Br J Haematol 1996;93:409-11. 15. Nanba K, Soban EJ, Bowling MC et al. Splenic pseudosinuses and hepatic angiomatous lesions. Distinctive feature of hairy cell leukemia. Am J Clin Pathol 1977;67: 415-26.

16. Piro LD, Carrera CJ, Carson DA et al. Lasting remissions in hairy-cell leukemia induced by a single infusion of 2chlorodeoxyadenosine. N Engl J Med 1990;322:1117-21.

17. Richards JM, Mick R, Latta JM. Serum soluble interleukin $-2 \mathrm{R}$ receptor is associated with clinical and pathologic disease status in hairy cell leukemia. Blood 1990;76:1941-5. 18. Saven A, Piro LD. 2-chlorodeoxyadenosine in treatment of hairy cell leukemia and chronic lymphocytic leukemia. Leuk Lymph 1994;11(Suppl. 2):109-14.

19. Tallman MS, Hakimian D, Rademaker AW et al. Relapse of hairy cell leukemia after 2-chlorodeoxyadenosine: long-term follow-up of the Northwestern university experience. Blood 1996;88:1954-9.

20. Yam LT, Li CY, LAM KW. Tartarate resistant acid phosphotase isoenzyme in the reticulum cell of leukemia reticuloendotheliosis. N Engl J Med 1971;284:357-60.

21. Žák P, Chrobák L, Podzimek K et al. Neobvyklý průběh leukémie s vlasatými buňkami s výraznou abdominální lymphoadenopatií, leukemickými infiltráty oční rohovky a kožními změnami. Vnitr Lek 1996;42:463-6.

22. Žák P, Chrobák L, Šimáková A et al. Zvětšení uzlin u leukémie s vlasatými buňkami a problematika výrazné abdominální lympfadenopatie. Vnitr Lek 1993;39:896-901.

\section{Submitted May 1997.}

Accepted June 1997.

Prof. MUDr. Ladislav Chrobák, CSc., Department of Clinical Hematology, University Hospital, Charles University, Faculty of Medicine, 50005 Hradec Králové, Czech Republic. 